\title{
A RORSCHACH X. TÁBLA FELSZÓLÍTÓ JELLEGÉNEK VIZSGÁLATA
}

\author{
MISKEI ANIKÓ ${ }^{1}$ - BAGDY EMỐKE ${ }^{1,2}$ - VARGHA ANDRÁS ${ }^{1}$ \\ ${ }^{1}$ Károli Gáspár Református Egyetem Pszichológiai Intézete \\ ${ }^{2}$ Pszichoszomatikus Ambulancia \\ E-mail: aniko.miskei@gmail.com
}

Beérkezett: 2019. december 31. - Elfogadva: 2020. február 29.

Háttér: A Rorschach-táblák felszólító jellegének validitása a szakirodalomban mindmáig kétséges. A hazai gyakorlatban Mérei Ferenc igazolta 1947-ben erre vonatkozó feltevéseit, amelyek ellenôrzése idôszerú feladat.

Célkitûzés: Munkánk a X. Rorschach-tábla felszólitó jellegének érvényességét vonta ellenörzés alá. Feltételeztük, hogy a Mérei Ferenc által leírt és értelmezett felszólitó jelleg megerösitést nyerhet, mely „az élettér kiaknázásának a lehetôsége; az a viselkedési mód, ahogy a vizsgálati személy bolyong a valóságnak abban a mezôjében, amelyhez kapcsolódik" (Mérei, 1979, 429).

Módszer: Három kutatási fázisban dolgoztunk. Az elsóben követtük a felszólitó jelleg kimunkálásához alkalmazott eredeti Mérei-féle elemzési rendszert. A második fázisban a felszólító jellegre irányadó szakirodalmi adatokat figyelembe véve, a Mérei-féle elemzési rendszerben jellegzetesnek mondható tartalmakat 614 vizsgálati személynél, a férfiak és nôk közti különbség, valamint iskolázottság szerint rangsoroltuk 10 változó mentén. A harmadik fázisban percepciós kisérleti helyzetet teremtve (komputer-képfelbontással) hat ingerhelyzetben, részeire bontva, szines, fekete-fehér, akromatikus árnyékolás, illetve kontúr változatban külön exponáltuk a X. tábla markáns részeit.

Eredmények: A kapott eredmények szerint a tartalmakra mind a szinek kavalkádja, mind a sok apró részlet hatással van. Ez megerösíti az eredeti Mérei-koncepciót, valamint saját felvetésünket is, és elösegíti az értelmezés további, adekvát használatát.

Kulcsszavak: Rorschach-teszt, felszólitó jelleg, validitásvizsgálat 


\section{BEVEZETÉS}

Hermann Rorschach személyiségdiagnosztikai tesztje mint a „tesztek királynője” (Searls, 2018) az elmúlt száz év során szinte minden nagy pszichológiai iskolát megihletett, hogy beillessze a módszert saját elméleti magyarázó rendszerébe. A behaviorista-kognitív szemléletû tesztológia a módszertan pszichometrikus tökéletesítésére törekedett, a pszichoanalitikus, jungi és egopszichológiai irányzat az individuális pszichodinamikus folyamatoknak, a tudattalan lelki zajlásnak a monitorozására helyezte és helyezi a hangsúlyt mindmáig. (Összegezi Császár-Nagy Noémi e kötetben megjelenô tanulmányában.) Mérei a munkássága során a Lewin-féle mezóelméleti elgondolást a teszt elméleti alapjaként értelmezte, a tesztet a szükségleti feszültség és a környezeti ingerek felszólító jellege közti dinamikus processzus tükrének tekintette (Mérei, 2002). Ily módon az egyes táblák egyfelôl individuális ingerek, másrészt alaki ingerjellegük közös mozgósító erôt is képvisel. A felszólító jelleg koncepció ebbe az elméleti keretbe úgy illeszkedik, mint zárba a kulcs. A táblák szukcessziója az - akár azonos - válaszminôségeket individualizálja, a tábla ingerforrása pedig konzekvensen mozgósít „valamilyen” szükségleti irányt. Mérei úttörố a felszólító jellegek vizsgálatában (Mérei, 1947). Az eltelt évtizedek kérdésessé teszik az egykori eredmények érvényességét. Kutatásunk célja, hogy a X. Rorschach-tábla felszólító jellegének elméleti vitapontjait empirikus mérésekkel tisztázzuk.

\section{ELMÉLETI HÁTTÉR}

\section{A Rorschach-teszt felszólitó jellegére vonatkozó kutatások áttekintése}

A hagyományos rorschachozók az értelmezést a reakcióhalmazok alapján végzik. „Öszszegezik a különbözô választípusokat és azoknak a számát, illetve összefüggéseiket tekintik jellegzetes tüneteknek" (Mérei, 1947, 116). Mindez viszont az jelenti, hogy az egy csoportba tartozó jegyek nemcsak, hogy egyenértékúek, de ugyanakkor egyjelentésû́ek is. Nem veszik azt sem figyelembe, hogy melyik táblán, a jegyzőkönyv melyik szakaszában bukkannak fel.

Nagy előrelépést jelentett Schachtel és Hartoch (1937, idézi Mérei, 1947) azon felismerése, hogy a vizsgálat az irreverzibilis folyamat, és a reakcióhalmazok helyett az értelmezésnél a szukcessziót tekinti alapnak. Így a válaszok során végighaladva magát a reakciómenetet követhetjük nyomon. Schachtel és Hartoch ugyanakkor még mindig nem vették figyelembe a táblák különbözôségét, ennek nyomán a jegyzôkönyvben a tábláktól független fázisokra osztották fel a szukcessziót. Az értelmezéskor feltételezték, hogy a „vizsgálati személy a vizsgálati helyzetben ugyanolyan lefolyásokon, értelmi, érzelmi és ösztönös mechanizmusokon át jut el a reakcióhoz, mint a valóságban" (Mérei, 1947, 116). Mérei a X-es tábla felszólító jellegét a lewini dinamikai, topológiai élettér fogalomból vezette le.

Mérei vizsgálatai teljesen Schachtel és Hartochétôl eltérô eredményt adtak: „a táblának mint ingerforrásnak válaszdetermináló erejük van, és ha tartalmi és formális 
tulajdonságaikra nézve hasonló reakciók különbözô jelentôségûek, ez elsôsorban a táblák különbözôségeivel magyarázható” (Mérei, 1947, 117). Mérei Lewin (1972) azon elméletére alapozott, mely leírja a pszichikus mezô gondolatát, illetve a felszólító jelleg létezését. Eszerint a mezôben lévô összes dolognak van valamilyen hatása. Csábításként vagy pedig akadályként hatnak a cselekvésre. A pszichikus mezô fogalma a „feszültségi rendszerre és az ebben végbemenô cselekvésre vonatkozik, s így kiterjed a cselekvést vezérló és befolyásoló indítékhálózatra is” (Mérei, 1972, 19).

A tárgyak felszólító jellege két dolog viszonyából tevôdik össze: a tárgy objektív adottságaiból és az én szükségleteiból. A tárgy adottságaiba nemcsak „funkcionális potenciálja” tartozik bele, vagyis hogy mire használható, hanem a története is a személy életében. Ez a három összetevô az, ami meghatározza a felszólító jelleget (Mérei, 2002, 425).

A Rorschach-próba esetében a kapott válaszokból csak akkor vonhatunk le következtetéseket, ha tisztában vagyunk azzal, hogy maga a teszt milyen objektív környezetet teremt. Minden reakciót mindig a teljes helyzetben kell nézni. Azt pedig egyértelmúen megállapíthatjuk, hogy a táblák nem egyformák. Már Hermann Rorschach is leírja az egyes táblák formai tulajdonságait. Utal is rá, hogy ugyanaz a kép különbözô személyekre eltérô hatással van. Mivel a Rorschach-táblák strukturálatlanok, ezért lehetôséget teremtenek arra, hogy sok szükséglet jelenjen meg, és így reprezentálja azokat a viselkedésmódokat, amelyeket az egyén a környezetében alkalmaz (Mérei, 2002, 19).

A felszólító jelleg kutatás mai napig meghatározó alakja volt Stephen Neiger, aki Mérei Ferenc munkáit német nyelvre fordítva elindította a felszólító jellegen alapuló értelmezési technikát, továbbá Mérei Ferenc munkásságát összefoglalta saját munkájában, és önálló kutatásával megerôsítette elôdje megfigyeléseit. Összegyújtötte a témával 1959-ig foglalkozó szakemberek munkáit, eredményeiket összegezte, megkísérelve táblánkként konklúziót alkotni az összecsengó kutatási eredményekre alapozva. Leírta, hogy fontos a reakciókból a szükségletekre következtetés, ehhez ismernünk kell a környezetet is, vagyis a tábláknak a percepciót irányító tulajdonságait. Munkájában végiggondolta a kultúrák közötti különbségeket, kitért a fehér szín szerepére, amely a keleti kultúrában eltér a nyugati kultúráétól, ugyanígy a fekete szín is más jelentéssel bír e két kultúrkörben. A táblák felszólító jellegét három aspektusból tartotta megvizsgálhatónak. Az elsô a szimbolikus jelentés, a második a táblák helye a tíz tábla között, a harmadik pedig az inger által mobilizált jelek tüneti értékei. Neiger szerint továbbá fontos, hogy minden tábla látszólag bôséges ingertulajdonítási lehetôséget kínál, de az egyes táblák különböznek az ingertartalmak konfigurációit, illetve azok hangsúlyosságát tekintve. Megkísérelte egybefogni a megalapozottnak tûnô felszólító jellegeket. Minden egyes táblánál tisztázta, hogy mit „vizsgál” a tábla, hogy mi a „felszólító jelleg alapja”, ahol többnyire az árnyékolás, szín, sötétség, Dzw (fehérség), egyértelmú szimbólumok megjelenése, a tábla sorrendben betöltött szerepe, illetve a tábla szervezettsége vagy annak hiánya játszották a fó szerepet. Leírta továbbá, hogy mik az egyes táblák hívójelei, illetve melyek azok a jelek, amelyek ritkák az adott táblán. Végigvette az adekvát és a leggyakoribb inadekvát megoldásokat. Majd a leírásban helyet kapott a tábla karakterjellemzóje, patológiai jellemzői, végül az érvényesség, használhatóság kérdéseit járta végig minden táblánál (Neiger, 1959). 


\section{A X. tábla felszólító jellegével kapcsolatos kutatások nemzetközi és magyar viszonylatban}

Ez a tábla kapja a legtöbb szimpátiaválaszt (Ames, 1952; idézi Mérei, 1947). Erôs elutasítást csak olyan esetekben tapasztalhatunk, amikor az egyén az ôt ért kudarcok miatt elfordul a világtól. Ennél még súlyosabb az az eset, amikor valaki képtelen választ adni a foltra (csôdöt mond, jele Versagen).

Nehéz ezt a táblát egészként értelmezni. Akik gyakorlatiasok, azok a forma alapján értelmezik, vulger válaszokat is adva. Akik inkább aprólékosak, azok hajlamosak beleveszni a kontúrba, és nagyon sok Dd választ adnak. A tábla sajátossága, hogy a részletek felé terel, jól strukturált, harmonikus színei minden érzelmi viszonyulásnak kedveznek, rokonszenvet vált ki, ezért kedvez az indulatáttételnek. „Ezt a jelentésadási folyamatot fogalmaztuk meg a X. tábla felszólító jellegében: az élettér kiaknázásának a lehetôsége; az a viselkedési mód, ahogy a vizsgálati személy bolyong a valóságnak abban a mezójében, amelyhez kapcsolódik" (Mérei, 1979, 429).

Neiger (1959) is részletesen foglalkozik a X. tábla felszólító jellegével. Megállapítja, hogy ez a tábla képezi a legnagyobb ingert a részletek felé fordulásra. A fehér részek elválasztják egymástól a különálló részleteket, és ezt a különállást a színek is felerôsítik, melyek nem keverednek egymással. Így rendkívül nehéz egységesen szemlélni a táblát és jó egész választ adni rá. Mivel a részletek határozott kontúrral rendelkeznek, ezért formájukra könnyen adnak a vizsgálati személyek vulger, többnyire állatválaszokat. A színek harmonikusak. Kimagaslóan gyakori a tábla pozitív rokonszenvi megítélése. Az élettér magába foglalja mind a személyt, mind pedig a pszichológiai környezetet. A pszichológiai környezet ugyanakkor nem azonos az objektív környezettel, hanem annak azon elemeit tartalmazza, amelyek felszólító jelleggel bírnak akár pozitív, akar negatív elōjellel. Az élettér azon faktorok összessége, amelyek meghatározzák egy adott pillanatban a viselkedésünket és a lehetséges történést. A vizsgálati személy lehetôséget kap, hogy azokat az elkülönült részeket vonja be az életterébe, amelyeket jellemzőnek tart.

A X-es táblának fontos szerepe van az állapotkép prognózisának megállapításában. Rapaport (1945, idézi Neiger, 1959) azt találta, hogy az aktuális feszültségi állapot jelenik meg a táblára adott utolsó válaszban. Megállapította, hogy ez a jövô tábla és a jövôhöz való viszonyulást vizsgálja. Azt is megmutatja, hogy mennyire döntésképes a személy a világban. Halpern (1953) az eddigi szerzőktôl nagyon eltérô felszólító jelleget tulajdonít a táblának: anyatábla gyerekekkel. Rabin (1959) szemantikus differenciál módszerrel vizsgálta a táblák felszólító jellegét. A következô jelzőket tulajdonították a X. táblának: ,jó, gyönyörú, tiszta, kellemes, boldog, világos, vékony, aktív, gyors és törékeny”.

Több kutatásban is a színt rendkívül ösztönzô tulajdonságnak tartották, mely képes elôhozni szubjektív tapasztalásokat, érzéseket és érzelmeket. Hays és Boardman (1975) vizsgálatukban Rabin 20 melléknév párjából kiválasztottak 12-t. Ezeket három csoportra bontották: érték, eró, aktivitás. Minden egyes csoportba négy szópár tartozott. A X. táblát az érték kategóriában az 5. helyre sorolták mint a legpozitívabbak egyikét. Az erô kategóriában a 7. helyre, az aktivitás kategórián belül pedig az elsô helyre került. Megállapították, hogy az érték és az erô faktorok között fordított összefüggés tapasztalható. Az érték faktoron belül a szín jelenléte növelte a táblák pozitív 
értékét minden színes tábla esetében. Az aktivitás faktorban a szín jelenléte miatt értékelték a színes táblákat a legaktívabbnak.

Összefoglalóan a X. tábláról elmondható, hogy felszólító jellege az élettér. A táblával vizsgálható, hogy az egyén az életterét milyen mértékben aknázza ki. Következtethetünk arra, hogy miként alakítja környezetét, illetve milyen módon mozgósítja érzelmeit. A felszólító jelleg alapja a sok szétszórt, részletgazdag forma. A formák jól izolálódnak, harmonikus színeik vannak. A részletekben sok lehetôség van arra, hogy vulger válaszokat kapjunk. Legmagasabb a rokonszenvi megítélése a sorozatban.

A tábla adekvát megoldása a sok D válasz, jó színvonalú formaválasz, állat válaszok és a vulger válaszok jelenléte. Továbbá még hatékonyabb, ha formavezérlésû színválaszok is vannak. Ezek alapján elmondható, hogy a személy emocionális viszonyulása az életkörülményekhez pozitív.

Versagen reakció azokban az esetekben tapasztalható, amikor az élettér extrém módon beszúkül, általában depressziós állapotban vagy skizofréniában fordul csak elô. Az ütközések, a színütközés jelezhet egyfajta hajlamot az életkörülmények elpusztítására. Az ilyen reakciót adó személy saját érdeke ellen tehet ártó szándékkal.

\section{HIPOTÉZIS}

A szakirodalmi áttekintés azt üzeni számunkra, hogy a X. Rorschach-tábla felszólító jellegére irányuló kutatások javarészt alátámasztják Mérei Ferenc azon feltevését, hogy a X. táblának a lewini értelemben vett élettér a felszólító jellege. Feltételeztük Mérei Ferenc korábbi eredményeinek érvényességét, azonos módszertani úton végezve a kontrollt. Figyelembe vettük azokat a mutatókat (részletgazdagság, színek), amelyek alátámasztották az érvényességet. Ugyanakkor törekedtünk arra, hogy valamelyest objektívebben szemléljük az adatokat és nyitottak legyünk egyéb lehetôségekre is. Az egyik legfontosabb célunk, hogy megfelelô statisztikai adatokkal alá is tudjuk támasztani a kapott eredményeket.

\section{ETIKAI VONATKOZÁSOK}

A kutatás alapjául szolgáló adatgyújtésre vonatkozó engedélyt a Károli Gáspár Református Egyetem Pszichológiai Intézetének Etikai Bizottsága adta ki Miskei Anikó szakdolgozó kérelmére 2007-ben. Az engedélyek a kutatás megkezdésének feltételeiként nem számozottan lettek kiadva. Az Etikai Bizottság csak 2017-ben vezetett be szabályozott engedélyezési rendszert az egyetemi kutatásokhoz.

\section{VIZSGÁLATOK}

Az 1. vizsgálatban megismételtük a Mérei-féle eredeti vizsgálatot. Itt egyetemi hallgatókkal 519 Rorschach-próbát vetettünk fel különbözó felnôtt személyekkel (243férfi, 276 nô; iskolai végzettség szerint 99-en alapfokú, 241-en középfokú, 177-en felsôfokú 
végzettséggel rendelkeztek). A jegyzôkönyvi válaszok mellé, pontosan követve Mérei (1947) eredeti vizsgálatának feladategységeit, három feladatot iktattunk be.

1. Választási próba

Instrukciója: „Kérem, hogy válassza ki azt a két táblát, amelyik a legjobban tetszett Önnek, utána azt a kettôt, amelyik a legkevésbé tetszett, majd felváltva válasszon a többi tábla közül, hol egy tetszôt, hol egy nem tetszôt."

2. Szimbólumértelmezési próba

Menete: A szabályosan lefolytatott vizsgálat és választási próba után a vizsgált személynek azt mondjuk, hogy: „Tekintse úgy ezeket a táblákat, mint különös szimbolikus festményeket. Adjon mindegyiknek címet!"

3. Asszociációs próba

Menete: Az egyes táblákhoz szabadon asszociáltatunk (mit idéz fel, mi jut róla az eszébe, milyen érzéseket idéz); különösen azokhoz, amelyeknél a vizsgált személy nem adott választ, vagy ütközés, telítôdés fordult elő.

Ebben a vizsgálatban kidolgoztuk a kapott tartalmak gyakorisági rendszerét is. Azt tapasztaltuk, hogy vannak olyan jegyzókönyvek, amelyek megmutatják, ha valamilyen konfliktus volt a múltban, vagy pedig aktuálisan fennáll valamilyen probléma, ezért nyolc csoportot alkottunk.

A 2. vizsgálatban arra voltunk kíváncsiak, hogy mely percepciós jegyek határozzák meg a válaszokat; 100 vizsgálati személy vett részt benne (nôk: 31, férfiak: 69; 2 személy általános iskolai, 1 személy szakmunkás végzettséggel, 58 érettségivel, 39 felsôfokú végzettséggel rendelkezett).

Ebben a vizsgálatban az eredeti folt hat változatát készítettük el (lásd 1. táblázat és 1. ábra), a vizsgálati kérdés pedig ez volt: „Nézze meg jól a képeket, és mondja meg, mire hasonlít a látott kép!”

1. táblázat. Percepciós variánsok jellemzôi a 2. vizsgálatban

\begin{tabular}{c|l}
\hline Sorszám & Percepciós variáns \\
\hline 1. & eredeti színes folt teljes egészében \\
\hline 2. & eredeti színes foltból 10+3+6-os área \\
\hline 3. & a folt akromatikus, Hd változata teljes egészében \\
\hline 4. & $10+3+6$-os área akromatikus, Hd változata \\
\hline 5. & eredeti folt kontúrja teljes egészében \\
\hline 6. & $10+3+6$-os área kontúros változata \\
\hline
\end{tabular}


1. variáns

$10+3+6$ área

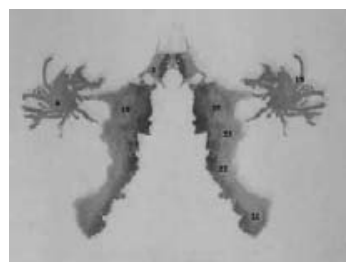

4. variáns

X. tábla akromatikus árnyék

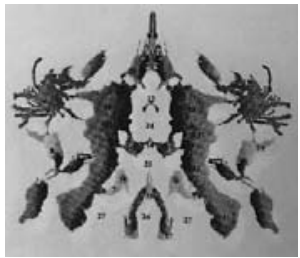

2. variáns eredeti X. tábla

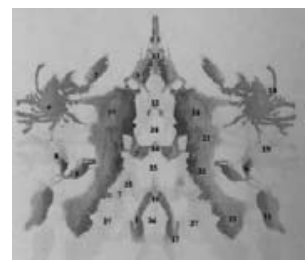

5. variáns $10+3+6$ kontúr

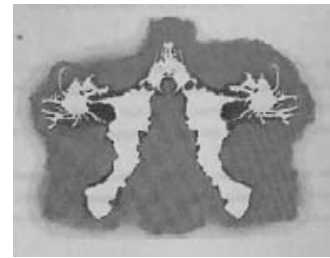

3. variáns

$10+3+6$ Hd árnyékoltságban

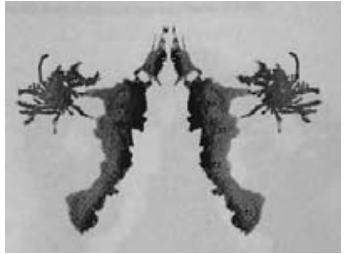

6. variáns

X. tábla kontúr

1. ábra. Percepciós variánsok ábrái a 2. vizsgálatban

\section{EREDMÉNYEK}

\section{Az 1. vizsgálattal kapcsolatos eredmények}

Elsô lépésben megnéztük, hogy a hagyományos 52 Rorschach tartalmi körbôl a X. tábla esetén melyek milyen gyakorisággal fordulnak elô. A leggyakoribbak a 2. táblázatban láthatók.

\section{2. táblázat. Tartalmi körök gyakorisága a X. tábla esetében}

\begin{tabular}{l|l|c|c}
\hline Gyakoriság sorszáma & Tartalom jele & Elöfordulás (db) & \%-os arány \\
\hline 1. & Víziállat & 469 & 18,46 \\
\hline 2. & Anat & 153 & 6,02 \\
\hline 3. & Víz & 123 & 4,85 \\
\hline 4. & Emlôs & 120 & 4,72 \\
\hline 5. & Obj & 111 & 4,37 \\
\hline
\end{tabular}

Saját szempontként arra is kíváncsiak voltunk, hogy a jegyzôkönyvben milyen gyakran jelenik meg az élet kifejezôdése direkt, illetve indirekt formában. És mivel nagyon összetett, sok részletbôl álló tábláról van szó, ezért azt is megnéztük, hogy milyen gyakran adnak a vizsgálati személyek Gkomb válaszokat (lásd 3. táblázat). 
3. táblázat. Egyéni szempontok elôfordulási gyakorisága

\begin{tabular}{l|c|c}
\hline Egyéni szempont & Elófordulás darabszáma & Százalékos arány \\
\hline Gkomb & 147 & 28,3 \\
\hline Élet indirekt & 59 & 11,4 \\
\hline Élet direkt & 28 & 5,4 \\
\hline
\end{tabular}

Direkt formának számított, amikor akár tartalomként, akár az asszociációban vagy címadásban valaki kimondta az élet szót. Például: „életet lehet benne látni”, „az életnek a változatosságát mutatja be”, „nyüzsgô élet”. Indirektnek vettünk minden olyan megnyilvánulást, ami az életre jellemzó nyüzsgést és sokszínúséget fogalmazta meg. Például: „tengeri élôvilág”, „víz alatti növény- és állatvilág”, „népi majális”. A Gkomb válaszoknál a személyek az egészból kiindulva adnak egy választ, mely az 519 jegyzôkönyv 28\%-ában fordult elô. Például „akvárium sok színes hallal”, „Riói karnevál”, „tengeri élóvilág”.

Ezután megnéztük a X. táblára adott szimpátiaválaszok gyakoriságát, hogy hány esetben találják szimpatikusnak a táblát (lásd 2. ábra). Itt szimp1 (szimp2, ..., antip2, antip1) értéke azt jelzi, hogy a vizsgált minta hány százaléka vélte úgy, hogy a X. tábla a tíz tábla közül a legszimpatikusabb (2. legszimpatikusabb, [...], 2. legellenszenvesebb, legellenszenvesebb).

Az esetek legnagyobb részében (30,5\%-ban), az elsô helyen, a legszimpatikusabbnak értékelték a X. táblát. Leolvasható továbbá, hogy alapvetôen pozitív viszonyulás figyelhetố meg a táblával kapcsolatban, mivel a X. táblát a vizsgálati személyek 55,5\%-a az elsố három legszimpatikusabb hely valamelyikére rangsorolta.

Ezután a gyakoriságokat $\chi^{2}$-próbával összehasonlítva megnéztük, hogy a vizsgált személyek neme milyen kapcsolatban van a tartalmakkal és vulger válaszokkal. A szignifikáns eltéréseket produkáló válaszok szerinti arányokat a 3. ábra mutatja be.

A 10-es áreára adott vulger „ember” válasz a férfiaknál gyakrabban, 8,6\%-ban, a nôknél ennél ritkábban, 4\%-ban jelenik meg $(\mathrm{p}<0,05)$.

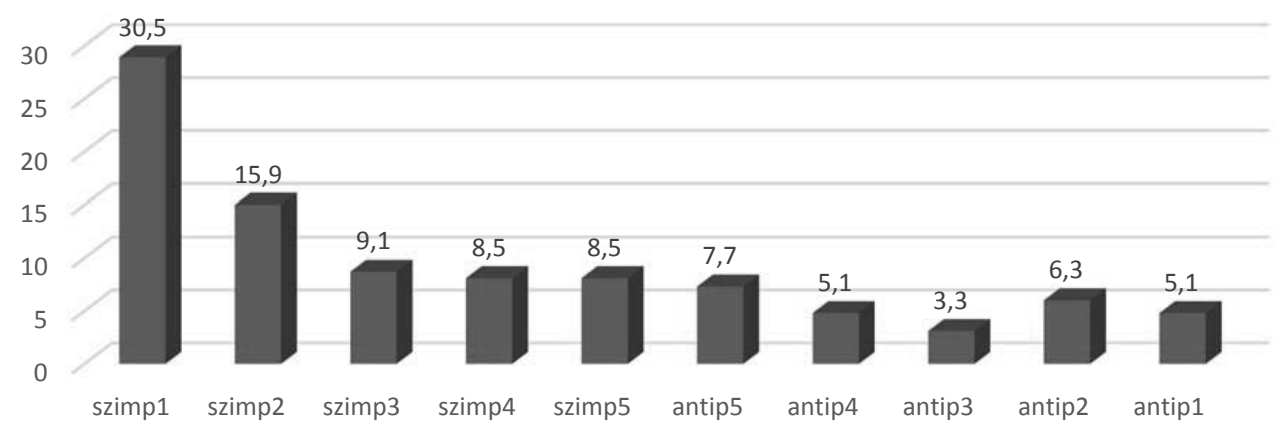

2. ábra. Szimpátiaválasztás százalékos arányai a X. táblán 
\%-os arányok nemenként

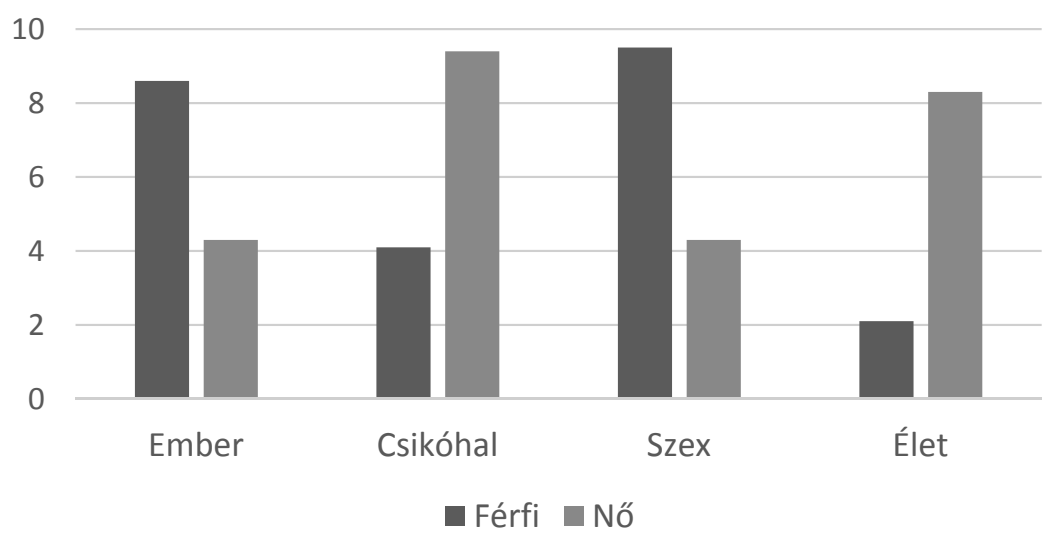

3. ábra. A nemek szerinti szignifikáns eltérések

A szintén 10-es áreára adott csikóhal válasz a nôknél több mint kétszer olyan gyakran jelenik meg, mint a férfiaknál. A nôk válaszainak 9,4\%-a, a férfiak válaszainak 4,1\%-a csikóhal erre az áreára $(\mathrm{p}<0,05)$.

A szokásos tartalmi körökben az ember és a szex válasz tér el csupán szignifikánsan a két nemnél $(\mathrm{p}<0,05)$. A férfiak több ember $(8,6 \%)$ választ adnak, a nôk ennél lényegesen kevesebbet $(4,3 \%)$.

Saját szempontként még megnéztük, hogy konkrétan hány esetben jelenik meg az „élet” kifejezés a jegyzőkönyvekben. Ebben az esetben is szignifikáns különbség látható a két nem között $(\mathrm{p}<0,01)$. Míg a nôk jegyzốkönyvének 8,3\%-ában, addig a férfiaknál csak 2,1\%-ban jegyezték le konkrétan az „élet” szót.

Az iskolai végzettség tekintetében mindössze a növény és térkép válasz tekintetében kaptunk szignifikáns eltérést. Előbbi esetében az alsóbb (alap- és középfokú) végzettséggel rendelkezôk $(9 \%)$ tértek el a felsôfokú végzettségúektôl (3\%) szignifikánsan $(\mathrm{p}<0,05)$ utóbbi esetén pedig a szakmunkások $(16 \%)$ emelkedtek ki szignifikánsan $(\mathrm{p}<0,01)$ a többiek közül.

Végül a családi állapot és az életkor kombinálásával alakítottunk ki releváns csoportokat (lásd 4. táblázat) és néztük meg az eltéréseket közöttük aszerint, hogy milyen tartalmú válaszokat preferáltak. Tekintve, hogy a csoportok részben átfedók, a $\chi^{2}$-próbás összehasonlításokat az alábbi független mintás kombinációkban végeztük el.

- K1 vs. K3+K4+K5: Szülökkel él vs. Kapcsolatban él;

- K2 vs. K3+K4+K5: Egyedül él vs. Kapcsolatban él;

- K3 vs. K4 vs. K5: Kapcsolatban él vs. Elvált;

- K3+K4+K5 vs. K6: Kapcsolatban él vs. Özvegy;

- K3+K4+K5 vs. K7: Fiatalabb vs. 65 év feletti;

- K1 vs. K4 vs. K8: Szülőkkel él vs. Kapcsolatban élő 40 év alatti vs. 65 év feletti. 
4. táblázat. Családi állapot szerinti csoportok életkorral kombinálva és tipikus válaszaik

\begin{tabular}{l|l}
\hline Csoport & Releváns tartalom, asszociáció, címadás \\
\hline K1. Szülókkel él $(\mathrm{n}=112)$ & Gyilkos virág; orchidea; mérgezó virág \\
\hline K2. Egyedülálló $(\mathrm{n}=104)$ & Hippi feje \\
\hline K3. Kapcsolatban él, nincs gyermeke $(\mathrm{n}=73)$ & Madarak a barlangban; szülés folyamata \\
\hline $\begin{array}{l}\text { K4. Kapcsolatban él, van gyermeke, } \\
40 \text { évesnél fiatalabb }(\mathrm{n}=71)\end{array}$ & Emberfej \\
\hline $\begin{array}{l}\text { K5. Kapcsolatban él, van gyermeke, } \\
40 \text { évesnél idôsebb }(\mathrm{n}=73)\end{array}$ & $\begin{array}{l}\text { Nyíló virág; fának a termése, amit reptet a } \\
\text { szél; kismadár; szakadék; szárazabb ág }\end{array}$ \\
\hline K6. Elvált $(\mathrm{n}=21)$ & $\begin{array}{l}\text { Koponyák és virágok; medvekoponya; madár } \\
\text { koponyája; tulipán; vidám színek egy szomo- } \\
\text { rú témához }\end{array}$ \\
\hline K7. Özvegy $(\mathrm{n}=10)$ & Kutya, kígyó \\
\hline K8. 65 év feletti $(\mathrm{n}=13)$ & Országút; sárga ószi falevél \\
\hline
\end{tabular}

Ezek az elemzéseink az alábbi eredményekre vezettek.

Az emberi testrész ( $\mathrm{Md}$ : „hippi feje”, „emberfej”) válaszok az özvegyeknél és a 65 év felettieknél egyáltalán nem fordultak elő, és a 40 év feletti kapcsolatban élók esetében is csak 5,5\%-os gyakorisággal, ami $\mathrm{p}<0,05$ szinten szignifikáns alacsonyabb volt, mint a többi, fôleg a K1 (22,3\%), K3 (20,5\%) és K4 (19,7\%) csoportban.

$\mathrm{Az}$ állat válaszokon belül a madár válasz a 65 év felettiek 30,8\%-ánál fordult elô a leggyakrabban $(\mathrm{p}<0,05)$, de az özvegyeknél érdekes módon nem volt ilyen válasz.

Az állat kategórián belül létrehoztuk az emlôs alkategóriát („kutya”, „patkány”, „ló”, „kecske”) is. Ez legnagyobb gyakorisággal a 65 év felettieknél $(46,2 \%, p<0,01)$, valamint az özvegyeknél $(30 \%, \mathrm{p}<0,05)$ jelent meg.

Hasonlóan az elôzô szemponthoz, a csúszómászóra vonatkozó tartalmak („kígyó”, „hernyó”) szintén a 65 év felettieknél (23,1\%), valamint az özvegyeknél (30\%) jelentek meg a leggyakrabban. Ezzel kapcsolatban a legszignifikánsabb különbség $(\mathrm{p}<0,01)$ a K5 vs. K7 összehasonlításban adódott.

\section{A 2. vizsgálattal kapcsolatos eredmények}

Itt a tábla azon tulajdonságait vizsgáltuk, amelyek befolyásolják a percepciót. Arra kerestük a választ, hogy a tábla mely sajátosságai teszik lehetôvé, hogy olyan válaszokat adjanak a vizsgálati személyek, amelyek összességében az élettérre, mint felszólító jellegre vezethetốk vissza. Hat helyzet volt, amelyre reagálniuk kellett a személyeknek (lásd 1. ábra és 1. táblázat).

Ezeket a helyzeteket hasonlítottuk össze és kerestük az eltéréseket. Abban az esetben, amikor hiányoztak a részletek (1., 3. és 5. variáns), mindig kevesebb volt a feleletszám. Az elsố két helyzetben, a színes képeken a feleletszám több volt, mint az akromatikus harmadik és negyedik variáns esetében.

A színes képekre adott tartalmak a jegyzókönyvekhez hasonlóan sok víziállatot tartalmaztak. A színek miatt gazdagabb volt a válaszok száma. Sok esetben használták a színeket lokalizációra is, például „kis kék krampuszok”, „vörös ördögök”, „a két rózsa- 
szín alak egy nôt ábrázol”. Az elsô két helyzet válaszai sok esetben implikálták, hogy a színek hatással voltak a percepcióra, például „tüzes varázsló”, „színes festékfoltok”, „zöldségek”, „túzijáték”, „virágcsokor”, „tavasz”, „vér”.

A színes helyzeteknél voltak leginkább olyan jellegú válaszok, amelyek az élet színességét és nyüzsgését szimbolizálják. Itt kaptunk olyan válaszokat, hogy „riói karnevál”, „túzijáték”, „tengerfenék növényvilága”, „szigetvilág”. A többi helyzetben az ilyen jellegú válaszok csak elvétve fordultak elô.

Már sok esetben a színes képeken is megjelennek az anatómiai válaszok, de ott érzékelhetô, hogy a színnek is szerepe van, például a 10-es ábrára, a piros foltra mondják azt, hogy tüdô. Az akromatikus képeknél sokkal több az anatómiai válasz, és sok esetben nem is magát a szervet látják, hanem annak a röntgenképét. Ha valaki hasonló válaszokat adott a színes és az akromatikus változatra, akkor is különbséget tett közöttük, például:

1. variáns: tüdő, $\quad 3$. variáns: tüdô + nikotin;

1. variáns: tüdô, $\quad 3$. variáns: beteg tüdô, valaki sokat dohányzott.

Az akromatikus ábrákon sokkal több agresszív válasz található, mint a színeseken, de hasonló arányú, mint a kontúroson. A kontúros helyzetekben, ahol már az árnyékolás sem befolyásolja a percepciót, a mozgásválaszok száma jelentôsen lecsökkent. A tartalmak az esetek nagyon nagy részében térkép, földrész válaszok.

\section{DISZKUSSZIÓ}

A Rorschach X. tábla felszólító jellege Mérei gondolatrendszerében az élettér. A tábla objektív tulajdonságai által determinált válaszok alátámasztják ezt a feltételezést. A legtöbb részlet ezen a képen található, melyek izolálódnak egymástól, lehetôséget teremtve a gazdag jelentésadásnak. A színek harmonikusak, így többnyire pozitív viszonyulást váltanak ki a személyekbôl a X. tábla kapcsán. A színek meghívnak tapasztalatokat, élményeket és érzelmeket, akár kellemeseket, akár kellemetleneket. A sok forma és a színek lehetôséget teremtenek arra, hogy az emberek szükségleteinek tág köre megnyilvánulhasson, így biztosítva azt, hogy az egyének többségére hatással van a tábla. A tábla adekvát megoldása a részletek végigjárása, vulger válaszok megemlítése, megfelelố forma vezérelt válaszok, melyekben a színnek is van jelentôsége, a rokonszenvi viszonyulás.

A vizsgálatban azt az eredményt kaptuk, hogy a leggyakoribb válasz a víziállat. Általában mind a forma, mind pedig a szín meghatározza ezeket a válaszokat. A kék szín alkalmas arra, hogy behozza a víz asszociációját, és ebbe az irányba terelje tovább a jelentésadást. Ahhoz, hogy a kép globálisan értelmet nyerjen az egyén számára, olyan átfogó kategóriába kell besorolnia azt, ahol ennyi szín és forma harmóniában megfér egymás mellett. Ennek a kívánalomnak teljesen megfelel a víz, melyben az élet sokszínúsége megtalálható.

Gyakori az anatómiai válasz, ahol a formának és a színnek együttesen is szerepe van, ami gyakran kelti a páros szerv képzetét. A színek közül is a piros a legdominánsabb az anatómiai válaszok létrejöttében, mivel behozza a vér képzetét, és hasonlít a szervek színére. 
A harmadik leggyakoribb válasz a víz, ami a már fentebb kifejtett okokon túl annak is köszönhetô, hogy ha konkrétan a víz, a tenger nem is jelenik meg, de sok a víziállat válasz.

Amint a 2. táblázatban látható, még a leggyakoribb tartalmi körök is csak kevés, 4-6\%-ban fordulnak elô. Ez azért van, mert a rengeteg lehetôségnek köszönhetôen az 52 tartalmi körból szinte az összesre találunk példát. Ezekben a jegyzôkönyvekben mindössze két tartalmi kör volt, melyek egyáltalán nem szerepeltek. A tartalmi körök mennyisége és az ezeken belül megoszló válaszok száma is bizonyítja azt a feltételezést, hogy a felszólító jelleg az élettér.

A 3. táblázat mutatja, hogy a Gkomb válaszok milyen nagy arányban fordulnak elô. Ezekben az esetekben a percepció egészlegesen ragadja meg a formákat és színeket, ezért tud a vizsgálati személy olyan választ adni, mely implikálja azt, hogy az egész kisebb részletekbôl tevôdik össze. Sok esetben ezeket a részleteket fel is sorolják.

Az élet direkt és indirekt megjelenése majdnem eléri a 17\%-ot. Habár ez plusz információt nem szolgáltat, de mindenféleképpen alátámasztja az eddigi feltevést.

A szimpátiasorrend eredményei (2. ábra) igazolják Hafner és Rosen (1964) eredményeit, amelyek szerint a színes táblák megítélése kedvezôbb, mint az akromatikus tábláké. Az pedig, hogy a X. táblát választották az esetek több mint felében az elsô három legszimpatikusabb valamelyikének, alátámasztja Hays és Boarman (1975) hasonló eredményét.

A 3. ábra rámutat, hogy a nôk és férfiak eltérôen reagálnak ugyanarra az ábrára. Míg a 10-es ábrára a férfiak inkább adnak ember válaszokat, addig a nôk ugyanerre az ábrára inkább csikóhal válaszokat adnak. Az az általános tendencia ebben az esetben is kitünt, hogy a férfiak jóval gyakrabban adnak szex válaszokat, mint a nôk. Kapcsolatban élô és szülookkel élố fiatal nôk a virág válaszokat kétszer olyan gyakran adták, mint a férfiak. Ennek az lehet az oka, hogy a virág a nôiesség szimbóluma, a nôi identitást jelképezi.

Az élet direkt és indirekt megjelenése a nôk jegyzôkönyvében kétszer olyan gyakori. A nôk inkább képesek a formákat és színeket olyan egésszé összerendezni, ami az élet sokszínúségére és nyüzsgésére utal. Különösen az asszociációkban és a címadásban jelent meg, hogy a nôk ragadták meg leginkább a tábla mögöttes tartalmát.

A végzettség tekintetében a növény válaszban akadtak eltérések az egyes csoportok között. A növény jegy mai értelmezése az, hogy az egyénben erôsebb a másikba kapaszkodás, a védelem és eltartás igénye. Az alacsonyabb iskolázottságúak vannak a leginkább rászorulva arra, hogy egzisztenciálisan máshonnan is támogatást kapjanak. A felsôfokú végzettségúek képesek arra, hogy egzisztenciálisan a saját lábukon megálljanak, és kevésbé van szükségük egy erôsebb ember támogatására.

Végzettség szerint a térkép válaszok mentén is elkülönülnek a csoportok, a legtöbbet a szakmunkások adták. A térkép intelligenciakomplexus válasz. A személy, aki térkép választ ad, múveltnek akar látszani. Olyan válasz, mellyel kompenzálni igyekszik belsố bizonytalanságát, amely a saját intellektusát érinti. Valószínúleg ez a helyzet azt a képzetet hozta létre bennük, hogy ez egy, az intellektuális színvonalukat is méró teszthelyzet.

Amikor a kor és a családi állapot szerinti csoportok közti különbségeket vizsgáltuk (vö. 4. táblázat), akkor több válasz esetében kaptunk szignifikáns eltérést. Az ember- 
részlet $(\mathrm{Md})$ válaszok esetén a fiatalabbak csoportjaiban (K1, K3 és K4) a magas, az idôsebbek csoportjaiban (K5, K7, K8) pedig az alacsony Md arányok tûntek ki. Általában az Md válasz az M viszonyában értelmezhetô. Ha mégis önmagában értelmezzük, akkor kapcsolati gátlásra utalhat. K1 a szüleikkel élốk csoportja. Ha még fiatalabbak, akkor a szülők lehetnek azok, akik gátló tényezôt jelentenek a kapcsolatok alakításában, létrehozásában és fenntartásában, hiszen míg otthon laknak, a szülôk feltételeinek kell megfelelniük. Ha valaki idôsebbként él együtt szüleivel, az már oka lehet annak, hogy a más emberekhez való kapcsolódása gátolt. A K3 a gyermek nélküli párok csoportja. Sok esetben a párok a másiknak nyújtanak elsóbbséget a többiekkel szemben, ami a barátok elmaradásához vezethet. K4 a gyermekkel rendelkezó fiatalabb párok csoportja. Ahol kisgyermek van, ott mindig a gyermeké az elsóbbség. Nagyon sok figyelmet és törôdést igényelnek, ezért a szociális kapcsolatok ebben az idôben beszúkülhetnek. Kevés olyan család van, akik találnak hasonló korú gyerekekkel rendelkezó baráti családokat, akikkel közös programokat szervezhetnek.

A másik tényezô, amely összefüggésbe hozható a fenti csoportokkal, a csúszómászó válasz. A csúszómászó függôségre utalhat. Két csoport van, ahol markáns a jelenlétük, az özvegyek és az idôsek. A függôség nemcsak alkoholt és gyógyszereket jelenthet, hanem szociális függôséget is, ami az idôsebbeknél sokszor megfigyelhetô. Keresik más emberek figyelmét és törôdését, és igyekeznek azt fenn is tartani.

A percepció vizsgálatánál bebizonyosodott, hogy a válaszok, amelyeket az élettérre adtak, mind a tábla színességének, mind pedig a sok apró részletnek is köszönhetók. A színes táblákra több tartalmat kapunk, több tartalmi körból. Mozgásválasz is több van, mint az akromatikus és kontúros helyzetekben. Ez megegyezik Little (1959) kutatásának eredményével, mely szerint a színes táblák felhívó jellege aktívabb, erôteljesebb az akromatikusoknál.

Az akromatikus Hd helyzetek szorongást és agressziót hívnak be a tartalmakba. Sokkal több a röntgen válasz például, ami fokozott szorongást jelent. De ha marad a színes helyzetben adott válasz, akkor is kap egy szorongásos aspektust, például tüdóbeteg vagy nikotinos tüdô válasz lesz. Mozgás az akromatikus helyzetben is több van, mint a kontúrosban, vagyis már az is elégnek bizonyul a mozgás megjelenéséhez, ha árnyékolt a kép. De az aktivitás ebben az esetben kisebb.

A kontúros helyzetekben a mozgásválaszok száma lecsökken, a képek statikusabbak. A tartalmakból az életet implikáló tartalmak eltûnnek. Néhány röntgen válasz olvasható, de a leggyakoribb a térkép, földrész válasz. Összességében elmondható, hogy a tartalmakat mind a színek, mind pedig a sok apró részlet meghatározza. Ezek együttesen támasztják alá a tábla felszólító jellegét.

\section{ÖSSZEFOGLALÁS}

Munkánkban azt a cél tûztük ki, hogy felülvizsgáljuk a X. tábla felszólító jellegét és az eredményeket statisztikai adatokkal is alátámasszuk. A felszólító jelleg mentén történó értelmezést Mérei Ferenc vezette be. A X. táblával kapcsolatban az volt a feltételezése, hogy a felszólító jelleg az élettér és annak kiaknázása. Ezt a feltételezést a legtöbb külföldi vizsgálat is alátámasztotta. 
A vizsgálathoz olyan anyagokat dolgoztunk fel, amelyek ugyanazon a módon lettek elkészítve, ahogyan Mérei is vizsgálta a felszólító jellegeket. A vizsgálati személyek a válaszaikon túl felállították a táblák szimpátia sorrendjét, címet adtak a tábláknak, és asszociáltak a képekre.

Az adatokat tartalmi szinten elemeztük, és a kapott eredmények mentén folytattuk a további vizsgálatokat. Megvizsgáltuk a táblák objektív jellemzôiit, amelyek magyarázhatják, hogy mely válaszokat adják a vizsgálati személyek a X. táblára.

A kapott eredmények alátámasztják a hipotézisünket, hogy a X. tábla felszólitó jellege az élettér. Erre utal a tartalmi körök száma, a válaszok széles terjedelme és az élet kifejezôdésének megnyilvánulásai.

A mozgás válasz megjelenése már az árnyékoltsághoz is köthetô, de az aktivitás fokozódik a színek megjelenésével. Az életre jellemzố válaszokat a színek és a részletek hívják be, együttesen determinálják a válaszokat.

A differenciált eredmények kedvezốn használhatók a Rorschach-teszt gyakorlati alkalmazásában.

\section{IRODALOM}

Hafner A. J., \& Rosen E. (1964). The meaning of the Rorschach inkblots, responses and determinants as perceived by children. Journal of Projective Techniques and Pesonality Assessements, T28, 192-200.

Halpern, F. A. (1953). A clinical approach to children's Rorschach. New York: Grune and Stratton.

Hays, J. R., \& Boardman, W. (1975). An Analysis of the Function of Color in the Rorschach. Journal of Personality Assessment, 39(1), 19-24.

Lewin, K. (1972). A mezóelmélet a társadalomtudományban. Budapest: Gondolat.

Little, K. B. (1959). Connotations of the Rorschach Inklbots. Journal of Personality, 27(3), 397406.

Mérei F. (1947). A Rorschach-táblák felszólító jellege. Magyar Pszichológiai Szemle, 16(3-4), 115125.

Mérei F. (1972). Kurt Lewin (1890-1947) (Előszó). In Lewin, K., A mezóelmélet a társadalomtudományban (pp. 5-39). Budapest: Gondolat.

Mérei F. (1979). A Rorschach-próba. Egységes jegyzet. Eötvös Loránd Tudományegyetem, Bölcsészettudományi Kar. Budapest: Tankönyvkiadó.

Mérei F. (2002). A Rorschach-próba. Budapest: Medicina Könyvkiadó Rt.

Miskei A. (2007). A Rorschach X. tábla felszólitó jellegének ellenôrzése. Szakdolgozat. Budapest: KRE.

Neiger, S. (1959). Introduction to the Rorschach Psychodiagnostic. IV. Valences of the cards sequence analysis. Toronto: Toronto Psychiatric Hospital.

Rabin, A. I. (1959). A contribution to the „meaning” of Rorschach's inkblots via the semantic differential. Journal of Consulting Psychology, 23(4), 368-372.

Searls, D. (2018). Rorschach-A tintafolt teszt és az észlelés rejtélyei. Budapest: HVG Könyvek. 


\title{
AN EXAMINATION OF THE IMPERATIVE CHARACTER OF RORSCHACH TABLE X.
}

\author{
MISKEI, ANIKÓ - BAGDY, EMŐKE - VARGHA, ANDRÁS
}

Theoretical background: The validity of the imperative meaning of the Rorschach tables in the literature is still uncertain. While Ferenc Mérei justified his assumptions in 1947, no control has been undertaken since then.

Objective: The objective of this study was to check the imperative meaning of Rorschach table X, based on the assumption that Ferenc Mérei's interpretation can be confirmed, namely that table X relates to "the potential for living space to be exploited; the behaviour of the subject as he roams the field of reality to which he is attached" (Mérei, 1979, 429).

Method: We worked in three phases. In the first one, we followed Mérei's original analytical system, applying it to the elaboration of the imperative character. In the second phase, taking into account facts and figures from the literature, we ranked the 614 subjects of the study for contents that are typical of Merei's analytical system, using 10 variables to assess differences between men and women and the subjects' education levels. In the third phase, after setting up an experimental situation (applying computer image resolution), we separately exposed the subjects to striking parts of table $X$ in six states of stimulus, with the images broken down into different categories: colour, black and white, achromatic shading and contour variations.

Results: The study showed that the contents of the subject's answers are influenced by both the variety of colours and a number of other small details. This reinforces both Mérei's original concept and our hypothesis and contributes to the proper interpretation of Rorschach results.

Keywords: Rorschach test, imperative character, validity test.

A cikk a Creative Commons Attribution 4.0 International License (https://creativecommons. org/licenses/by/4.0) feltételei szerint publikált Open Access közlemény, melynek szellemében a cikk bármilyen médiumban szabadon felhasználható, megosztható és újraközölhetô, feltéve, hogy az eredeti szerzô és a közlés helye, illetve a CC License linkje és az esetlegesen végrehajtott módosítások feltüntetésre kerülnek. (SID_1) 